\title{
The Effectiveness of Use of the Learning Media "Relay Board" in Increasing Student's Interest in Learning Mathematics at MTs N Darul Ilmi Banjarbaru
}

\author{
Ridho Rahmatullah ${ }^{1 *}$ Riyadi $^{2}$ Diari Indriati ${ }^{3}$ \\ ${ }^{1}$ Postgraduate of Mathematics Education, Faculty of Teacher Training and Education, Universitas Sebelas \\ Maret, Surakarta, Indonesia \\ ${ }^{2}$ Department of Mathematics Education, Universitas Sebelas Maret, Surakarta, Indonesia \\ ${ }^{3}$ Department of Mathematics and Natural Sciences, Universitas Sebelas Maret, Surakarta, Indonesia \\ *Corresponding Author. Email: Ridho_2206@student.uns.ac.id.
}

\begin{abstract}
initial key word relay board is a game-based learning media competition between teams, where each player on the team will answer the questions given by taking turns each step of the answer. This study aims to obtain information about the effectiveness of the use of learning media "board relay" in increasing students' interest in learning mathematics. This research is an experimental study with a one group pretest posttest design. The research subjects were students of MTsN Darul Ilmi Banjarbaru for the academic year 2021/2022. The type of research used is quantitative research with data collection techniques using questionnaires. Questionnaire indicators to measure interest in learning are 1) feeling happy. 2) student involvement, 3) interest, and 4) student attention. This study discusses about increasing reading interest based on the N-Gain scale which is grouped into several indicators. The results showed that the use of learning media "relay board" can increase students' interest in learning mathematics.
\end{abstract}

Keywords: Relay board, Interest in learning, Madrasah tsanawiyah.

\section{INTRODUCTION}

Mathematics is a branch of science that has an important role in human life. The development of science and technology is closely related to mathematics [1]. based on the results of the 2018 PISA study released by the OECD, the average score for mathematics in Indonesia reached 379 with an OECD average score of 487 . Indonesia was ranked 72 out of 78 countries listed. Many factors can increase the average score of mathematics in Indonesia, one of which is by increasing students' interest in learning mathematics.

Someone who has an interest in a lesson, then that person will tend to really study it, while someone who is less interested in a lesson then tends to be reluctant to learn it [2]. interest is also an important determinant of educational success [3][4] High learning interest tends to produce high achievement, on the contrary, low learning interest will result in low learning achievement. Students with high interest tend to actively participate in the learning process.[5] indicators of interest in learning are divided into 4, namely [2]: (1) Feelings of pleasure, If students have feelings of pleasure towards certain lessons, there is no sense of being forced to learn. (2) student involvement, a person's interest in an object that causes the person to be happy and interested in doing learning activities. (3) interest, relates to the student's driving force towards interest in an object, person, activity or it can be an affective experience stimulated by the activity itself. and (4) student attention, student attention is the concentration of students on observation and understanding, to the exclusion of others. Teachers can use learning media in every material presented. By using learning media students' interest in learning can increase [6][7]. 
Educational media is a component of learning resources or physical vehicles that contain instructional materials in the student environment that can stimulate students to learn [8] learning media is one of the teaching aids for teachers to deliver teaching materials, increase student creativity and increase student attention in the learning process. With the media students will be more motivated to learn, encouraging students to write, speak and imagine getting stimulated. Thus, through learning. media can make the teaching and learning process more effective and efficient as well as establish good relations between teachers and students.

Learning media Relay board is a game-based learning media competition between teams, where each player on the team will answer the questions given by taking turns each step of the answer. The steps in the relay board game are (1) students form teams with each team consisting of 4-6 people, (2) students line up in front of their respective team's relay boards. Then the teacher explains the rules of the game while demonstrating how to play. (3) Children compete to answer the questions that have been given, students who are at the front of the team row may only answer one step then he must take the queue at the back. (4) The team that can complete the answer correctly and quickly is the winning team. Game-based learning media can attract students' interest because students feel learning while playing, can sharpen students' brains, and to provide relaxation but a challenging impression with various levels of problems [9]. The game also trains fine motor and gross motor skills of students who play it in the form of balance, cooperation, cohesiveness, and togetherness [13]. This is in line with research conducted by Ahmad Syawaludin, Sidrah Afriani Rachman and Khaerunnisa which showed that students' interest in learning after being given learning with the help of game-based learning media were 25 students (92\%) answered that they were happy with the subject matter being taught, and $80 \%$ students answered that they were happy with the learning, so it could be concluded that the learning media was effective in increasing students. interest in learning [8]. Another study conducted by Nilza Humaira, Ulfa Lu'luilmaknun, Ratih Ayu, Nourma Pramestie, and Sripatmi, stated that 55 students $(93.75 \%)$ students agreed to learn mathematics by using game-based learning media, while 4 students $(9.09 \%)$ students do not agree with learning mathematics using game-based learning media, there are several reasons students agree with the use of game-based learning media in learning mathematics, including: (1) students become interested in learning, (2) learning becomes fun, (3) students do not get bored of learning, (4) games need to be used in learning activities, (5) learning materials become easy to understand, (6) students can learn while playing, (7) students become challenged, (8) students are more relaxed in learning, ( 9) students do not get bored of learning [11]. Based on the results of the study, educational game-based learning media can increase students' interest in learning mathematics.

Based on the description above, research is needed to find out about the effectiveness of the use of learning media "relay board" in increasing students' interest in learning mathematics. This will provide insight for teachers in the selection of game-based learning media to increase students' interest in learning mathematics. This will also help students increase their interest in learning mathematics.

\section{RESEARCH METHODS}

This research is an experimental study with the research design used is One Groups Pretest-Posttest Design (Figure 1). One group pretest-posttest design is a research activity that provides an initial test (pretest) before being given treatment, after being given treatment then giving a final test (posttest) [10].

\begin{tabular}{|lll|}
\hline $\mathrm{O}_{1}$ & $\mathrm{X}$ & $\mathrm{O}_{2}$ \\
Pre-test & Treatment & Post-test \\
\hline
\end{tabular}

Figure 1. Research design one-group pretestposttest

The population in this study were students of Madrasah Tsanawiyah Negeri Darul Ilmi in the academic year 2021/2022. The sample in this study was class VIII MtsN Darul Ilmi Banjarbaru who was taking semester 1 in the 2021/2022 academic year. The data collection technique used is a questionnaire of students' interest in learning mathematics. This questionnaire refers to the validity of the student's interest in learning mathematics questionnaire using content validity. The reliability of the mathematics learning interest questionnaire using Cronbach Alpha. Data were analyzed using N-Gain.

The data used in this study is quantitative data. Taken from the pre-test and post-test data using a questionnaire of students' interest in learning mathematics. Then, the data obtained were analyzed using N-Gain. N-gain score aims to determine the effectiveness of the use of a particular method or treatment in research. The formula used is as follows: 


$$
<g>=\frac{\text { Post test score }- \text { pre test scor }}{\text { ideal score }- \text { pre test score }}
$$

The results of the N-Gain score are divided into several categories [12], including:

Table 1. Categories normalized N-Gain

\begin{tabular}{|l|l|}
\hline$\langle\mathrm{g}\rangle$ & Categories \\
\hline$>0.7$ & High \\
$0.3(\langle\mathrm{~g}\rangle) 0.7$ & Medium \\
$<0.3$ & Low \\
\hline
\end{tabular}

\section{RESEARCH RESULTS AND DISCUSSION}

The results of the study discuss the effectiveness of the use of learning media "relay board" in increasing students' interest in learning mathematics. Results of N-Gain analysis can be seen in Table 2 as follows:

Table 2. Normalized N-Gain

\begin{tabular}{|c|c|c|c|c|}
\hline \multirow[b]{2}{*}{ Sample } & \multicolumn{2}{|c|}{ Mean Scores } & \multirow[b]{2}{*}{$<g>$} & \multirow[b]{2}{*}{ Criteria } \\
\hline & $\begin{array}{l}\text { Pre- } \\
\text { test }\end{array}$ & $\begin{array}{l}\text { Post- } \\
\text { test }\end{array}$ & & \\
\hline 1 & 32 & 68 & 0.75 & High \\
\hline 2 & 35 & 65 & 0.66 & Moderate \\
\hline Overall & 83 & 140 & 0.705 & High \\
\hline
\end{tabular}

Based on Table 2, the criteria for interest student learning using relay board media tends to be high. These results can be seen from the $\mathrm{N}$-gain value of sample 1 of 0.75 or in the high category and the $\mathrm{N}$ gain value of sample 2 of 0.666 or in the medium category. Thus, the average value of $\mathrm{N}$-gain for students is 0.705 or in the high category.

There are 4 indicators in the dangket to determine students' interest in learning. These indicators are: feelings of pleasure, student order, interest and attention of students. The results of the $\mathrm{N}$-Gain calculation on the 4 indicators of student interest in learning are presented in Table 3 as follows:

Based on the results of the analysis, it can be seen that a significant increase occurred in the happy feeling indicator of 0.71 or in the high category, while the indicators of student order, interest, students' attention is in the medium category.

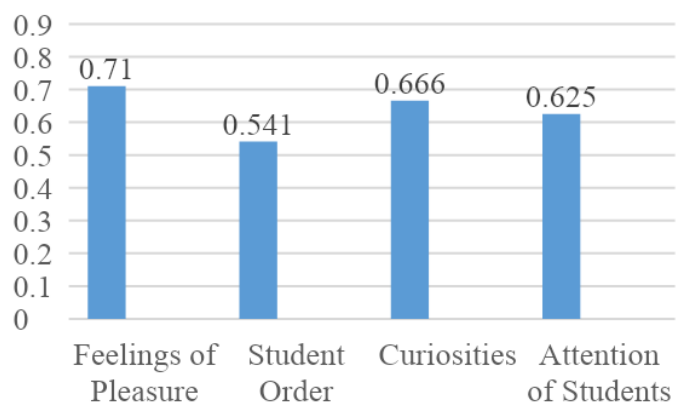

Figure 2. Category indicators of student interest in learning based on N-Gain

Based on Table 2 and Figure 2, it can be seen that the use of relay board media is effectively used to increase students' interest in learning mathematics.

\section{CONCLUSION}

Based on the results of the study, it can be concluded that there is an effective use of gamebased learning media "relay board" in increasing students' interest in learning mathematics. The application of game-based learning media "relay board" in learning can increase students' interest in learning mathematics. This is evidenced by the criteria for the $\mathrm{N}$-gain value in the sample of students of MTsN Darul Ilmi Banjarbaru which tends to be high after the application of the "relay board" game-based learning media. It is recommended for educators to be able to carry out learning using the help of "relay board" game-based learning media. This will help increase students' interest in learning mathematics. This research can also be a reference for developing relay board

Table 3. Category indicators of student interest in learning based on N-Gain

\begin{tabular}{|l|l|l|l|l|}
\hline \multirow{2}{*}{ Indicators } & \multicolumn{2}{|l|}{ Mean Scores } & \multirow{2}{*}{$<\mathrm{g}>$} & Criteria \\
\cline { 2 - 4 } & Pre-test & Post-test & & \\
\hline Feelings of Pleasure & 42 & 69 & 0.71 & High \\
\hline Student Order & 32 & 58 & 0.541 & Moderate \\
\hline Curiosities & 35 & 65 & 0.666 & Moderate \\
\hline Attention of Students & 32 & 62 & 0.625 & Moderate \\
\hline
\end{tabular}


learning media, which is a game-based learning media.

\section{REFERENCES}

[1] Aini Aulia, Nengah Parta, and Santi Irawati, "understanding the concept of the inverse function of students through jigsaw cooperative learning", JKPM Postgraduate UNM, Vol.1 NO.2, 2017, PP 106-112

[2] Slameto. 2010. "Learning and the factors that influence it". Jakarta: PT. Rineka Cipta

[3] Bettri Yustinaningrum. "The Implementation of E-Learning Web-based Model Centric Course(Edmodo) torard The Mathematics' Interest and Learning Outcomes". Al-Jabar: Jurnal Pendidikan Matematika. Vol.9, No.1, 2018. Pp.25-32.

[4] Balasubramanian K, Jaykumar V and Fukey L N. "Student Preference towards the Use of Edmodo as a Learning Platform to Create Responsible Learning Environment". Procedia - Soc. Behav. Vol.4,No.1.pp.63-71.

[5] Ai Sadidah, Ariyadi Wijaya."'Developing Mathematics Learning Set For Special-Need Junior HighSchool Student Oriented To Learning Interest And Achievement". Jurnal Riset Pendidikan Matematika. Vol.3,No.2.pp.150-161.

[6] Trisniawati, Mahfudah Titi Muanifah, Sri Adi Widodo, "Effect of Edmodo towards interests in mathematics learning", Journal of Physics: Conference Series, vol.1188, Iss.1, 2019

[7] Rebecca lazarides and Angela Ittel, Mathematics Interest and Achievement: What Role Do Perceived Parent and Teacher Support Play? A Longitudinal Analysis, International journal of Gender, science and Technology, Vol.2, No.5, 2012, 208-231

[8] Azhar Arsyad. 2014. "Learning media". Jakarta: PT. King Grafindo Persada.

[9] Ornella Alika and Elvira Hoesein Radia, "Development of Learning Media Based on Cross Puzzle Game in Science Learning to Improve Learning Outcomes", Journal of Research in Science Education, 2021, Vol.7, pp.173-177

[10] Ahmad Syawaluddin, Sidrah Afriani Rachman, and Khaerunnisa, Developing Snake Ladder Game Learning Media to Increase Students' Interest and Learning Outcomes on Social Studies in Elementary School, SAGE Journals 2020, vol.10, pp1-11
[11] Nilza Humaira at.al, the perspectives of mathematics Pre-Service Teacher Student Toward the Use of Educational Game in Mathematics Learning, JRPM,2020, Vol.3, No.2, pp.85-93

[12] Arikunto, S. 2010. practical approach". Jakarta: Rineka Cipta.

[13] Yuli Ana Sitio, Budi Usodo, Riyadi, "The Value of Character Education in Engklek Games at Primary School", Atl. Press, Vol.534, 2020, pp.133-141 